\title{
OVARIAN ACTIVITY IN ULTRASOUND IMAGE AND MILK PROGESTERONE CONCENTRATION IN POSTPARTUM DAIRY COWS
}

\author{
R. DOLEŽEL ${ }^{1}$, K. KARLBERG ${ }^{2}$, E. ROPSTAD ${ }^{2}$ \\ ${ }^{1}$ Clinic of Obstetrics, Gynaecology and Andrology \\ University of Veterinary and Pharmaceutical Sciences, 61242 Brno \\ ${ }^{2}$ Department of Reproduction and For ensic Medicine, Norwegian College of Veterinary \\ Medicine, Oslo, Norway
}

Received September 18, 1992

\begin{abstract}
Doležel, R., K. Karlberg, E. Ropstad: Ovarian Activity in Ultrasound Image and Milk Progesterone Concentration in Postpartum Dairy Cows. Acta vet. Brno, 62, 1993: 173-178.

Eighteen pluriparous dairy cows were ultrasonographically observed twice a week from day $9-10$ post partum to the 2 nd ovulation. Milk samples were taken three times a week and progesterone was assayed by RIA. Before the 1st postpartum ovulation and during the 1 st sexual cycle, $1.09 \pm 1.09$ and $1.8 \pm 1.11$, respectively, subordinate follicles and $1.5 \pm 0.52$ and $2.4 \pm 0.72$, respectively, follicular waves were found. The 1st ovulation occurred $17.9 \pm 5.04$ days after parturition, the length of the 1st sexual cycle was $19.4 \pm 4.66$ days and clinical involution of the uterus was completed $22.6 \pm 4.34$ days after parturition.

The period from parturition to the time of the 1st postpartum ovulation and the length of the 1st sexual cycle were positively correlated with the number of follicular waves during the periods. About $81 \%$ of the first postpartum follicular waves and $88 \%$ of the 1 st ovulations occurred in the ovary contralateral to the previous pregnant uterine horn. The differences disappeared after the 1st postpartum ovulation. Average values of milk progesterone were discovered during the 1st and 2nd sexual cycles at day $5-7(5.9 \pm 4.78$ and $6.3 \pm 5.16 \mathrm{ng} / \mathrm{ml})$ and at day $10-12$ $(5.6 \pm 5.83$ and $11.4 \pm 7.74 \mathrm{ng} / \mathrm{ml})$.
\end{abstract}

Follicular wave, ovulation, luteal structure, laterality

A large variety of postpartum ovarian activity in cows was discovered using rectal palpation and morphological investigation after slaughter. Simultaneous occurrence of growth, maturation, luteinization and regression in follicular population is described by Morrow et al. (1966), Wagner and Hansel (1969), Schirar and Martinet (1982), Dufour and Roy (1985). Various quality and lifespan of the first postpartum luteal structures are cited by Lauderdale et al. (1968), Duby et al. (1985), Rutter and Randel (1985). Development of follicles influence the quality and lifespan of following luteal structures (Smith, 1986, Inskeep et al., 1988). For this reason continual observation of follicular population is important for the understanding of a resumption of sexual cycle in postpartum cows.

Ultrasound imaging makes it possible to observe the dynamics of follicular development. Pierson and Ginther (1987a), Rojamahendran and Walton (1988) state sequential patterns of development and regression (follicular waves) during sexual cycle in cattle. Likewise dominant follicles and follicular waves are described before the first postpartum ovulation and during the following sexual cycle in dairy (Rojamahendran and Taylor 1990, Savio et al. 1990) and beef (Braden et al., 1986; Murphy et al. 1990) cows.

The objectives of our study were to characterize ovarian activity in cows using ultrasound scanning and milk progesterone assay from day 9-10 postpartum to the second postpartum ovulation. 


\section{Materials and Methods}

Eighteen pluriparous dairy cows (Norwegian cattle) calving between August 26 and October 25 were included in the experiment. Two cows with pathological conditions (ovarian cysts, retentio secundinarum and endometritis) were excluded by the end of the experiment. Grass silage and concentrates formed principal part of diet. Calves were removed immediately after parturition. Cows were milked and were observed for estrus twice daily.

The cows were regularly investigated by rectal palpation and transrectal ultrasonography (Scanner 400 or 403, PIE Medical, The Netherlands) twice a week, ovarian structures and uterine horns were printed in different planes by video copy processor (Model P61E, Mitsubishi, Japan) and follicles $>3 \mathrm{~mm}$ in diameter, corpora lutea and width of uterine horns (approximately in a third of its length) were evaluated. Ovarian structures were individualy identified by reference to their position and diameter in sequential images. Gradual growth of a dominant follicle (follicle in diameter at least $2 \mathrm{~mm}$ more than other follicles) was considered a follicular wave. Day after estrus was determined as the time of ovulation. If estrus was not observed, day 2 after investigation of the largest dominant follicle, followed by disappearance of the follicle and formation of a CL, was determined as the time of ovulation. The largest follicle at day 9-10 after calving was considered as the 1st postpartal dominant follicle. The time from which the width of uterine horns did not decrease gradually and distinctly was determined as the time of clinical involution of uterus.

The samples of whole milk were taken three times a week from day 9-10 after calving to the end of the 2nd postpartal sexual cycle and they were stored at $-20^{\circ} \mathrm{C}$ until they were assayed for progesterone by RIA. Student t-test was used for statistical evaluation.

\section{Results}

The number of follicular waves before and after the 1st postpartal ovulation, total number of follicles, time of the 1st ovulation, length of the 1st postpartal sexual cycle and time of clinical involution of uterus are included in Table 1. One follicular wave before the 1st ovulation occurred in 9 of 10 cows which ovulated before day 20 post partum. Two follicular waves were discovered in 1 cow which ovulated before day 20 and in all cows which ovulated later. Two follicular waves during the lst sexual cycle were discovered in 8 of 9 cows with the 1st sexual cycles shorter than 20 days. One follicular wave occurred during one short sexual cycle. Three follicular waves were discovered in 5 of 7 cows with longer 1st sexual cycles, two and four follicular waves occurred in the remaining 2 cows. The mean length of the 1st postpartum sexual cycle in cows which ovu-

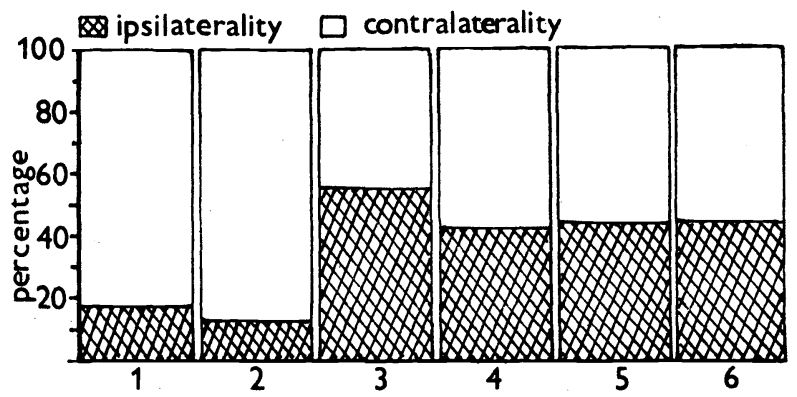

Fig. 1. Laterality of follicular waves and ovulations in rostpartum cows.

1 - 1st follicular wave: previous pregnant uterine horn

2 - 1st ovulation: previous pregnant uterine horn

3 - follicular waves during ist sexual cycle: previous pregnant uterine horn

4 - follicular waves during 1st sexual cycle: cyclical CL

5 - 2nd ovulation: previous pregnant uterine horn

6 - 2nd ovulation: cyclical CL 
lated before and after day 20 post partum was $17.8 \pm 4.61$ and $22.2 \pm 3.55$ days.

The first contralateral postpartal follicular wave and the 1st contralateral postpartal ovulation in relation to the previously pregnant uterine horn was discovered in 13 of $16(81 \%)$ and in 14 of $16(88 \%)$ cows. Differences in laterality of follicular waves and ovulations decreased after the 1st postpartal ovulation (Fig. 1).

The mean concentrations of milk progesterone at day $5-7$ and $10-12$ of the 1st and 2nd sexual cycles are included in table 2. Significantly $(p<0.05)$ higher concentration was discovered at day $10-12$ of the 2nd postpartum sexual cycle $(11.4 \pm 7.74 \mathrm{ng} / \mathrm{ml})$ in comparison with concentration in the same period of the previous sexual cycle $(5.6 \pm 5.83 \mathrm{ng} / \mathrm{ml})$.

Table 1

Number of follicular waves from calving to the 1st ovulation (A) and during the 1st sexual cycle (B), number of subordinate follicles from calving to the 1st ovulation (C) and during the 1st sexual cycle (D), interval (day pp) from calving to the 1 st ovulation $(E)$ and to the complete uterine involution (F), and length (days) of the 1st sexual cycle (G)

\begin{tabular}{|c|c|c|c|c|c|c|}
\hline $\mathbf{A}$ & B & C & D & E & $\mathbf{F}$ & G \\
\hline $\begin{array}{c}1.5 \\
\pm 0.52\end{array}$ & $\begin{array}{c}2.4 \\
\pm 0.72\end{array}$ & $\begin{array}{c}1.9 \\
\pm 1.04\end{array}$ & $\begin{array}{c}1.8 \\
\pm 1.11\end{array}$ & $\begin{array}{c}17.9 \\
\pm 5.04\end{array}$ & $\begin{array}{c}22.6 \\
\pm 4.34\end{array}$ & $\begin{array}{c}19.4 \\
\pm 4.66\end{array}$ \\
\hline
\end{tabular}

Mean \pm s. d.

Table 2

Concentration of milk progesterone at day 5-7 and 10-12 of the 1st and 2st postpartum sexual cycles in cows

\begin{tabular}{|l|c|c|}
\hline & 1st sexual cycle & 2nd sexual cycle \\
\hline Day $5-7$ & $5.9 \pm 4.78 \quad$ p 0.05 & $6.3 \pm 5.16$ \\
Day $10-12$ & $5.6 \pm 5.83 \quad$ p & $11.4 \pm 7.74$ \\
\hline
\end{tabular}

Mean \pm s. d.

\section{Discussion}

Well-balanced numbers of subordinate ovarian follicles $>3 \mathrm{~mm}$ in diameter before and after the 1st ovulation suggest a similar follicular activity in these periods. The largest follicle at day 9-10 after calving was considered the 1st postpartum dominant follicle even if Savio et al. (1990) discovered the 1st dominant follicle already at day $6.8+1.8$ post partum. One follicular wave we discovered in cows before the 1st ovulation which occurred before day 20 post partum. Two follicular waves were discovered in cows which ovulated later. Two follicular waves during the 1st postpartum sexual cycle occurred in most cows with the sexual cycle shorter than 20 days. Three follicular waves occurred during longer first postpartum sexual cycles. Our results stand comparison with normal sexual cycles in which the number of follicular waves relate to the length of the sexual cycles and in which length of follicular waves are approximately 1 week (Pierson and Ginther 1987a; Rojamahendran and Walton 1988). Rojamahendran and Tylor (1990) state 2 follicular waves during the 
1st postpartum cycle in 18 of 21 cows. Periods among investigation (3 and 4 days) prevented to evaluate the length of follicular waves in our experiemnt.

Term of the 1st postpartum ovulation $17.9(11-28)$ days is shorter than it is usually discovered in crossbreds of Bohemian Pied and Holstein-Friesian cows (e.g. average value 27.74 days is stated by Kudláč and Vlček (1970) but the term is comparable with the results of other authors (Morrow et al. 1969; Garcia and Lars on 1982; Duby et al. 1985; Savio et al. 1990). We discovered a shorter length of the 1st postpartum sexual cycle in cows which ovulated before day 20 post partum than in cows which ovulated later. Some of the 1st postpartum luteal structures in cows having a short sexual cycle represented in ultrasound image corpus hemorhagicum (diameter $<20 \mathrm{~mm}$, low echogenity of luteal tissue, sometimes cavity) throughout its lifespan. Shorter 1st postpartum sexual cycles, the relation of the length of the 1st sexual cycle to the term of the 1st postpartum ovulation, and different quality of the lst postpartum corpus luteum are described by Morrow et al. (1966), Lauderdale et al. (1968), Garcia and Larsson (1982), Duby et al. (1985), Rutter and Randel (1985), Schallenberger (1985). Slightly higher levels of serum progesterone (0.6$1.0 \mathrm{ng} / \mathrm{ml}$ ) are often accompanied by small atypical luteal structures in ovaries at day 20-25 post partum (Doležel et al. 1991). Practically the same average levels of milk progesterone $(5.94$ and $6.25 \mathrm{ng} / \mathrm{ml}$ ) at day 5-7 and different levels at day $10-12$ post partum $(5.56$ and $11.38 \mathrm{ng} / \mathrm{ml})$ in the 1 st and the 2nd postpartum sexual cycle support clinical findings in our experiment. Perry et al. (1991) state similar concentrations of serum progesterone during the first 4 days in the 1st and 2nd postpartum sexual cycles but they describe higher concentration from day 5 to 8 of the 2 nd sexual cycle.

We registered $81 \%$ of the 1st postpartum follicular waves and $88 \%$ of the 1st ovulation occurring in contralateral ovary in relation to the previously pregnant uterine horn and the differences disappeared after the 1st postpartum ovulation. Inhibitory influence of corpus luteum graviditatis or pregnant uterine horn to early postpartum activity of ipsilateral ovary are shown by Morrow et al.(1968), Schirar and Martinet (1982), Bellin et al. (1984), Pierson and Ginther (1987b, c). Likewise, Kotík (1990) reports higher percentage of cows with first ovulation on the contralateral ovary in relation to the previous pregnant uterine horn. The differences are more distinct in primiparous cows with left-side previous pregnancy. Our results suggest more distinct inhibitory effect of previously pregnant uterine horn to early postpartum follicular development in comparison with effect of cyclical corpus luteum. On the other hand Rajamahendran and Taylor (1990) did not discover any relation of pregnancy to laterality of the 1st postpartum ovulation.

\section{Ovariální aktivita $\mathrm{v}$ ultrazvukovém zobrazení a koncentrace progeste- ronu $v$ mléce u krav $v$ poporodním období}

18 pluriparních mléčných krav bylo vyšetřováno ultrazvukem 2krát týdně od 9. - 10. dne po porodu do 2 . ovulace. Třikrát týdně byly odebírány vzorky mléka pro stanovení progesteronu RIA metodou. Před 1. poporodní ovulací a v průběhu 1. pohlavního cyklu jsme zjistili $1,9 \pm 1,09$ a $1,8 \pm 1,11$ podř́zených folikulů, $1,5 \pm 0,52$ a $2,4 \pm 0,72$ folikulárních vln. První ovulace proběhla 17,9 . $\pm 5,04$. den po porodu, délka 1 . pohlavního cyklu činila $19,4 \pm 4,66$ 
dní a klinická involuce dělohy byla zakončena $22,6 . \pm 4,34$. den po porodu. Délka periody od porodu do 1 . ovulace i délka 1. pohlavního cyklu pozitivně korelovala s počtem folikulárních vln $\mathrm{v}$ průběhu uvedených period. $81 \%$ prvních poporodních folikulárních vln a $88 \%$ prvních ovulací proběhlo na kontralaterálních ováriích $\mathrm{k}$ předtím březímu děložnímu rohu. Rozdíly $\mathrm{v}$ počtu folikulárních vln a ovulací v závislosti na lateralitě se po 1. poporodní ovulaci vyrovnaly. $\mathrm{V}$ průběhu 1. a 2. poporodního pohlavniho cyklu jsme zjistili hodnoty progesteronu 5.-7. den $5,9 \pm 4,78$ a $6,3 \pm 5,16 \mathrm{ng} / \mathrm{ml}, 10 .-12$. den $5,6 \pm 5,83$ a $11,4 \pm 7,74 \mathrm{ng} / \mathrm{ml}$.

\section{Овариальная активность в үльтразвүковом изображении и концентрация прогестерона в молоке коров в послеродовой период}

Исследовали 18 многорожавших коров ультразвуком 2 раза в неделю с 9-10 дня после отела до 2 овуляции. Три раза в неделю проводили отбор проб молока с целью определения прогестерона методом PIA. Перед 1 послеродовой овуляцией и в ходе 1 полового цикла нами были установлены $1,9 \pm 1,09$ и 1,8 $\pm 1,11$ подчиненных фолликулов, $1,5 \pm 0,52$

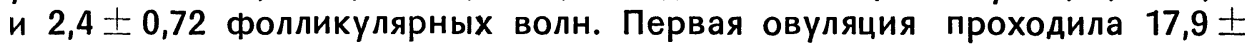
$\pm 5,04$ суток после отела, продолжительность 1 полового цикла достигала 19,4 \pm 4,66 суток и клиническая инволюция матки была завершена $22,6 \pm 4,34$ суток после отела. Продолжительность периода от отела до 1 овуляции и продолжительность 1 полового цикла находились в позитивной корреляции с численностью фолликулярных волн в течение приведенных периодов. 81 \% первых послеродовых фолликулярных волн и $88 \%$ первых овуляций протекали на контраратеральных овариях к забеременевшему до этого углу матки. Разница численности фолликулярных волн и овуляций в зависимости от латеральности после 1 послеродовой овуляции исчезла. В ходе 1 и 2 послеродовых половых циклов нами были установлены величины прогестерона на 5-7 сүтки $5,9 \pm 4,78$ и $6,3 \pm 5,16 \mathrm{нг} / \mathrm{мл}, 10-12$ сүтки - 5,6 $\pm 5,83$ и $11,4 \pm 7,74$ $\mathrm{Hr} / \mathrm{Mn}$.

\section{References}

BELLIN, M. E.-HINSHELWOOD, M. M.-HAUSER, E. R.-AX, R. L.: Influence of suckling and side of corpus luteum or pregnancy on folliculogenesis in postpartum cows. Biol. Reprod., 31, 1984: 849-855

BRADEN, T. D.-MANNS, J. G.-CERMAK, D. L.-NETT, T. M.-NISWENDER, G. D.: Follicular development following parturition and during the estrous cycle in beef cows. Theriogenology, 25, 1986: 833-843

DOLEŽEL, R. - KUDLÁC̆, E.-NEDBÁLKOVÁ, J.: Morphology of the reproductive tract and serum progesterone concentrations in cows within 45 days after parturition. Acta vet. Brno, 60, 1991: $181-192$

DUBY, R. T.-BROWNING, T.-CAREY, D.-BLACK, D. L.: Progesterone synthesis and histology of postpartum bovine corpora lutea. Theriogenology, 23, 1985: 619-630

DUFOUR, J. J.-ROY, G. L.: Distribution of ovarian follicular populations in the dairy cow within 35 days after paturition. J. Reprod. Fert., 73, 1985: 229-235

GARCIA, M. - LARSSON, K.: Clinical findings in post partum dairy cows. Nord. Vet. Med., 34, 1982: 255-263

INSKEEP, E. K. - BRADEN, T. D. - LEWIS, P. E. - GARCIA-WINDER, M. - NISWENDER, G. D.: Receptors for luteinizing hormone and follicle-stimulating hormone in largest follicles of postpartum beef cows. Biol. Reprod., 38, 1988: 587-591 
KOTf́K, J.: Obnovení pohlavního cyklu u krav po porodu ve vztahu $\mathrm{k}$ lateralitě předchozí březosti, pořadí parity a ročnímu období. Atest. práce, VŠV Brno, 1990: 56 p

KUDLAC̆, E. - VLČEK, Z.: Klinické změny na pohlavním ústrojí a obsah baktérií $\mathrm{v}$ děloze krav po normálním porodu. Vet. Med. (Praha), 15, 1970: 11-19

LAUDERDALE, J. W. - GRAVES, W. E. - HAUSER, E. R. - CASIDA, L. E.: Relation of postpartum interval to corpus luteum development, pituitary prolactin activity, and uterine involution in beef cows. Wisc. Agric. Exp. Sta. Res. Bull. 270, 1968: 42-48

MORROW, D. A. - ROBERTS, S. J. - McENTEE, K.: Postpartum ovarian activity and uterine involution in dairy cattle. J. Amer. Vet. Ass., 149, 1966: 1 596-1 609

MORROW, D. A. - ROBERTS, S. J. - McENTEE, K.: Latent effects of pregnancy on postpartum ovarian activity in dairy cattle. J. Anim. Sci., 27, 1968: $1408-1411$

MORROW, D. A. - ROBERTS, S. J. - McENTEE, K.: Postapartum ovarian activity and involution of the uterus and cervix in dairy cattle. Cornell. Vet., 59, 1969: 173-210

MURPHY, M. G.-BOLAND, M. P.-ROCHE, J. F.: Pattern of follicular growth and resumption of ovarian activity in post-partum beef suckler cows. J. Reprod. Fert., 90, 1990: 523-533

PERRY, R. C. - CORAH, L. R.-KIRACOFE, G. H.-STEVENSON, J. S. - BEAL, WE: Endocrine changes and ultrasonography of ovaries in suckled beef cows during resumption of postpartum estrous cycles. J. Anim. Sci., 69, 1991: 2 548-2 555

PIERSON, R. A.- GINTHER, O. J.: Follicular populations during the estrous cycle in heifers. I. Influence of day. Anim. Reprod. Sci., 14, 1987: 165-176

PIERSON, R. A.- GINTHER, O. J.: Follicular populations during the estrous cycle in heifers. II. Influence of right and left sides and intraovarian effect of the corpus luteum. Anim. Reprod. Sci., 14, 1987: 177-186

PIERSON, R. A. - GINTHER, O. J.: Intraovarian effect of the corpus luteum on ovarian follicles during early pregnancy in heifers. Anim. Reprod. Sci., 15, 1987: 53-60

RAJAMAHENDRAN, R. - TAYLOR, C.: Characterization of ovarian activity in postpartum dairy cows using ultrasound imaging and progesterone profiles. Anim. Reprod. Sci., 22, 1990: $171-180$

RAJAMAHENDRAN, R. - WALTON, J. S.: Follicular development and corpus luteum formation in postpartum dairy cattle. Proc. 11 th Int. Congr. Anim. Reprod. Artif. Insem., University College, Dublin, 2, 1988: 60

RUTTER, L. M. - RANDEL, R. D.: Luteal competency during the resumption of ovarian cyclicity in postpartum Brahman cows. Theriogenology, 5, 1985: 713-725

SAVIO, J. D. - BOULAND, M. P.-HYNES, N.-ROCHE, J. F.: Resumption of follicular activity in the early post-partum period of dairy cows. J. Reprod. Fert., 88, 1990: 569-579

SCHALLENBERGER, E.: Gonadotropins and ovarian steroids in cattle. III. Pulsatille changes of gonadotropin concentrations in the jugular vein postpartum. Acta Endocrinol. (Copenh), 109, 1985: $37-43$

SCHIRAR, A. - MARTINET, J.: Postpartum ovarian activity and its interaction with the uterus in resuming cyclic activity post partum. In: KARG, H. - SCHALLENBERGER, E.: Factors influencing fertility in the postpartum cow. The Hague (Boston) London, Martinus Nijhoff Publishers 1982: 67-94

SMITH, M. F.: Recent advances in corpus luteum physiology. J. Dairy Sci., 69, 1986: 911-926

WAGNER, W. C. - HANSEL, W.: Reproductive physiology of the postpartum cow. Clinical and histological findings. J. Reprod. Fert., 18, 1969: 493-500 